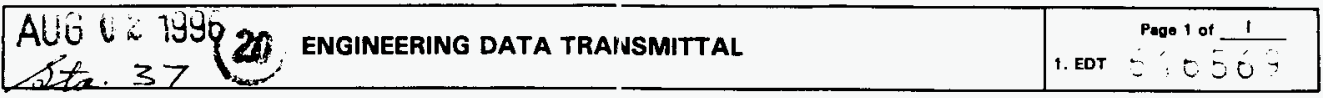

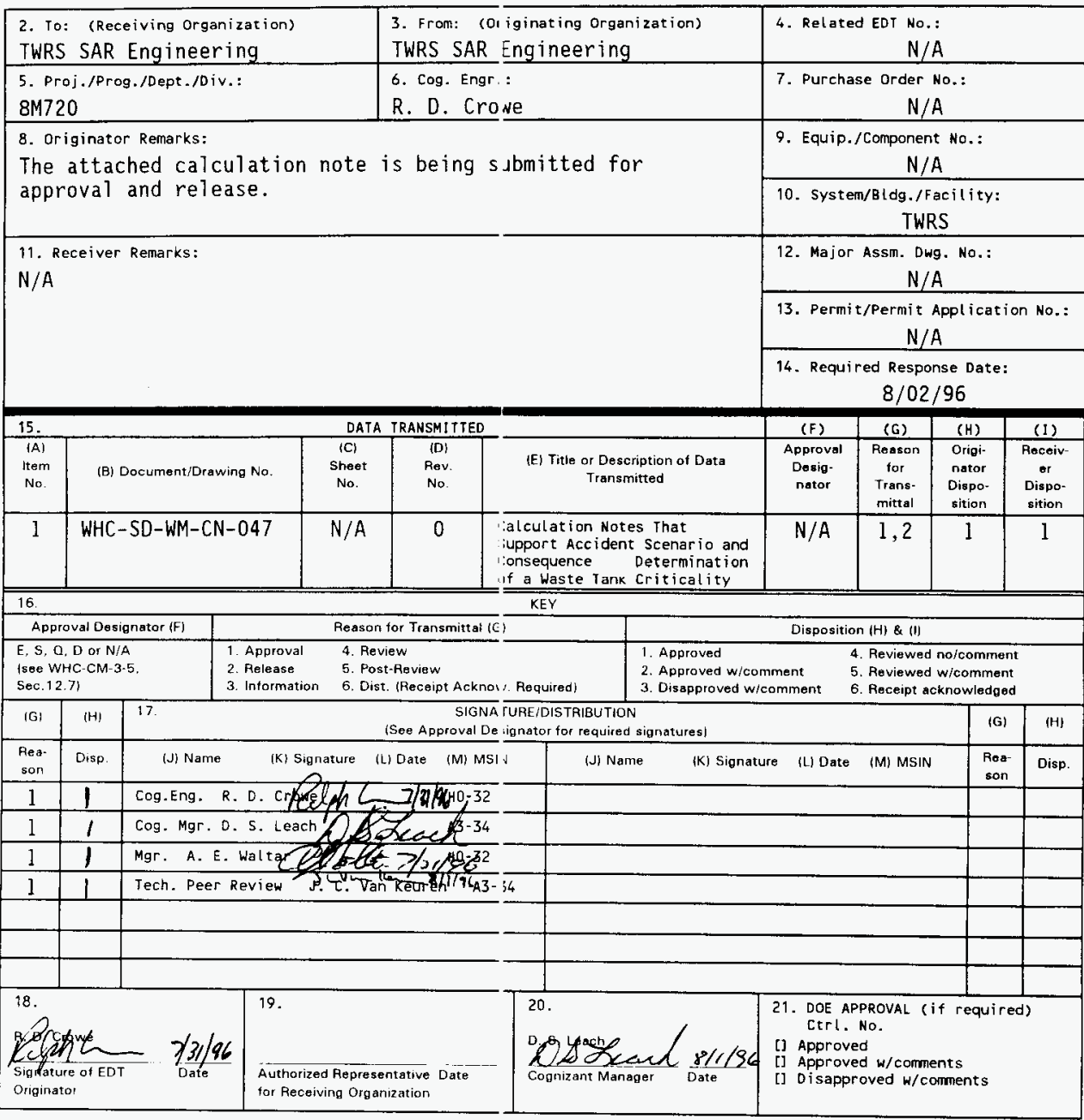

BD-7400-172-2 (04/94) GEF097 


\section{CALCULATION NOTES THAT SUPPORT ACCIDENT SCENARIO AND CONSEQUENCE DETERMINATION OF: A WASTE TANK CRITICALITY}

Ralph D. Crowe

Robert M. Marusich

Westinghouse Hanford Company, Richland, WA 99352

U.S. Department of Energy Contract DE-AC06-87RL10930

$\begin{array}{lll}\text { EDT/ECN: } & 616569 & \text { UC: } 510 \\ \text { Org Code: } & 8 M 720 & \text { Charge Code: N1FWl } \\ \text { B\&R Code: } & \text { EW3120071 } & \text { Total Pages: } 12\end{array}$

Key Words: Criticality, FSAR, and Safety Analysis

Abstract: The purpose of this calculation note is to provide the basis for criticality consequences for the Tank Farm Safety Analysis Report (FSAR). Criticality scenario is developed and details and description of the analysis methods are provided.

TRAOEMARK DISCLAIMER. Reference herein to any specific commercial product, process, or service by trade name, trademark, manufacturer, or ctherwise, does not necessarily constitute or imply its endorsement, recommendation, or favoring by the United States Government or any agency thereof or its contractors or subcontractors.

Printed in the United States of America. To obtain copies of this document, contact: WHC/BCS Document Control Services, P.O. Box 1970, Mailstop H6-08, Richland WA 99352, Phone (509) 372-2420; Fax (509) 376-4989.
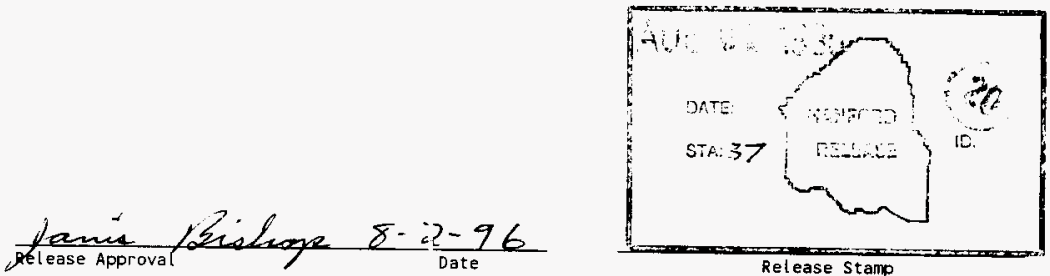

\section{Approved for Public Release}


Calculation Notes That Support Accident Scenarit) and Consequence Determination For a Waste Tank Criticali:y
Ralph Crowe

Nuclear Analysis and Characterization

Purpose - Although no credible scenario has been identified leading to a criticality in a waste tank, DCRT, catch tank, or 200 series tank or in a mistransfer from PFP, such a criticality is presumed and its consequences are calculated in this section.

Assumptions - The quantity of the transferred waste to be analyzed was chosen to be 500 liters of a $10 \mathrm{~g}$ Pu/L solution. This solution is transferred at $4.7 \mathrm{~L} / \mathrm{s}(75 \mathrm{gal} / \mathrm{min})$. The concentration and quantity is based on a estimate of the quantity of plutonium that could conceivably be transferred from PFP providing that numerous failures occurred. Transfers with a higher plutonium concentration would be overly conservative. Lower concentrations would give too large critical volumes. $10 \mathrm{~g}$ Pu/L gives a critical sphere with reasonable diameter and size.

Scenario -It is assumed, notwithstanding the inordinate number of failures required, that a solution containing thousands of grams of plutonium accumulates in PFP waste receiver tank D-8. This waste cannot go critical in tank $D-8$ as the layer thickness is too small. The contents of tank D-8 are routed to a previously empty 244-TX DCRT for the same reason. The transferred waste will not go critical in 244-TX either. When the PFP waste is transferred to the DST, the PFP waste forms a sphere in the existing waste. The radius of this sphere increases until a critical volume is reached and the sphere goes critical.

As the criticality proceeds, there is a burst in the curve of fission rate versus time followed by a rapid shutdown. The shutdown is effected as a. consequence of the fission energy release that results in thermal expansion, density reduction from the formation of very small bubbles, fissile dilution through mixilg from convective currents with expulsion of part of the critical mass. Early in the burst, the small bubbles are formed. As the burst continues, the amount of dissolved gas increases enough to support the formation and expansion of larger bubbles. As the burst is terminated, there is a sudden internal pressure relief resulting in rapid steam production and the release of the dissolved gases. The gases and steam along with th: fission gas and a fraction of the waste are carried into the headspace of the tank. The increase in the pressure in the headspace is relieved by renting a fraction of the headspace through HEPA filters. The pressure o: the steam also will cause the critical volume to expand and disperse Because the tank is so large as compared with the critical volume, the expansion will result in dispersal of the critical volume, without reasiembly. The DST criticality is therefore modeled as a single burst. 


\section{Input Data}

Accidental Transfer of 500 liter of $10 \mathrm{~g} /$ iter Pu solution transferred to DST at a rate of 75 gallons per min

Critical volume for $10 \mathrm{~g} /$ liter is 300 liters (Rogers 1996 ) volume $:=300$-liter

The critical volume for a $10 \mathrm{~g}$ Pu/liter solution has been calculated to be $300 \mathrm{~L}$ (Rogers 1996 ) with a critical radius of $41.5 \mathrm{~cm}$.

$$
\text { Critical radius } \quad r_{\text {crit }}:=\left[\frac{3(\text { volume })}{4 \cdot \pi}\right]^{\frac{1}{3}} \quad r_{\text {crit }}=41.528 \cdot \mathrm{cm}
$$

At the fill rate of $4.7 \mathrm{~L} / \mathrm{sec}$, it takes 63 seconds to reach a critical volume.

$$
\text { Time to reach critical radius } \quad V(r):=\frac{4 \cdot \pi}{3} \cdot r^{3} \quad \frac{V(r \text { crit })}{75 \cdot \frac{\mathrm{gal}}{\mathrm{min}}}=63.401 \cdot \mathrm{sec}
$$

\section{Nuclear Constants}

Nuclear constants assumed fe.r dilute Pu solution (Duderstadt 1971)

$$
\begin{array}{clll}
\text { fermi age } & t=26 \mathrm{~cm}^{2} & \text { diffusion length } & L_{m}:=\sqrt{1.73 \cdot \mathrm{cm}^{2}} \\
\text { beta effective } & 3 \text { eff }:=0.002 & \text { reflector savings } & \delta r:=57 \cdot \mathrm{cm}
\end{array}
$$

The $k_{\text {eff }}$ of the sphere during the fill as a function of the sphere radius can be calculated from the following equation.

$K$ effective calculated fr $3 m \mathrm{~m}$ infinity and two-group buckling.

$K$ infinity chosen to give $k=1$ at critical radius.

$$
k_{\text {inf }}:=1.130 \quad k(r):=k_{\text {inf }} \frac{\exp \left[-\tau\left(\frac{\pi}{r+\delta r}\right)^{2}\right]}{1+L_{n}{ }^{2} \cdot\left(\frac{\pi}{r+\delta r}\right)^{2}} \quad k\left(r_{\text {crit }}\right)=1 \quad r_{\text {crit }}=41.528 \cdot \mathrm{cm}
$$

This equation can be used to Find the reactivity insertion rate as the sphere goes critical. The realtivity insertion rate, typically expressed in $\$ / \mathrm{sec}$, is a measure of the rate at which the number of fissions is increasing. In the limit of i small change, the reactivity insertion rate is the change in reactivity for a small increase in the sphere radius divided by the time required :or the radius to increase. The rate at which the radius increases is a function of the fill rate. From the following equation, the reactivity insertion rates for the $10 \mathrm{~g} P u / L$ sphere at critical radius of ire $41.5 \mathrm{~cm}$ is 0.57 \$ $/ \mathrm{sec}$. 


$$
\frac{\frac{\mathrm{k}\left(\mathrm{r}_{\text {crit }}+0.01 \cdot \mathrm{cn}\right)}{\beta_{\mathrm{eff}} \mathrm{k}\left(\mathrm{r}_{\text {crit }}+0.01\right.} \cdot \mathrm{k}\left(\mathrm{r}_{\text {crit }}\right) \cdot \mathrm{cm}\left(\mathrm{r}_{\text {crit }}\right)}{\frac{\mathrm{V}\left(\mathrm{r}_{\text {crit }}+0.01 \cdot \mathrm{cn}\right)}{\mathrm{m}\left(\mathrm{r}_{\text {crit }}\right)}}=0.567 \cdot \frac{\text { dollar }}{\mathrm{sec}}
$$

It is possible to predict the neutronic response to a reactivity driving function by using point kinetics, as long as appropriate feedback models are employed. For small systems (with tight spatial coupling), this method will produce results that replicate both experimentally measured power and pressure curves reasonably well as shown in the reference (Hetrick 1993) for both dilute plutonium and uranium solutions. These calculations are compared to critical solution excursions measured at Silene. Hetrick's point kinttics model for fissile solutions includes both the Doppler feedback (fissionable material temperature) effect and the feedback associated with the change in volume of the system. The change in volume includes the rmal expansion of the fluid as well as radiolytical gas bubble formation.

For pure plutonium and very righly enriched uranium systems, it is expected that the Doppler coefficient is either nearly zero, or may in fact be positive. This is because absorption resonances also include a dominant fission component, and the Doppler broadening of these resonances may increase neutron production faster than the increase in neutron loss (Hetrick 1971). For fast transients, the radiolytic gas bubble generation rate may dominate the thermal expansion effect, and so this will be a significant feedback effect for solution criticalities. The gas generation rate is calculated by using the $G$ value for the solution, which is the quantity of gas produced per amount of energy deposited by fission in the solution. There is a threshold effect, and so some amount of energy deposition is required before the solution becomes saturated and large bubbles may form.

One of the cases in the reference (Hetrick 1993) is for a case similar in many respects to the postulated tank farm criticality. The calculated transient is for a one-region plutonium solution in a cylindrical geometry with a radius of $40 \mathrm{~cm}$. The fuel concentration is $10.5 \mathrm{~g} / \mathrm{liter}$. A neutron temperature coefficient of reactivity and a volume expansion coefficient was calculated from multi-group cross sections using transport theory. The power and reactivity for a step reactivity input of 4 dollars are shown. After some initial positive feedback from rising system temperature, the transient terminates rapidly with the formation of radiolytic gas. The hypothetical waste tank criticality, if it did occur, would occur in a fluid with a $G$ value reasonably close to water. The maximum inertial pressure for the pulse in the Hetrick reference is 0.58 $\mathrm{MPa}$ and the energy yield is $87 \mathrm{MJ}$. 
For the DST criticality, theje is a similar volume and Pu concentration. The temperature and volume espansion coefficients should be comparable with the Hetrick calculation. Since the DST criticality reactivity insertion rate is under $1 \$ / \mathrm{sec}$, as compared to the $4 \$$ step increase in reactivity assumed in Hetricl's calculation, the energy yield and pressure for the DST criticality should be bounded by Hetrick's calculated transient.

Based on the similarity of the described DST criticality and the calculations performed by Het rick, it is assumed that 89 MJ of energy (equivalent to $2.62 \times 1018$ fissions) is released in the DST criticality with inertial pressures of ak out $0.6 \mathrm{MPa}$. It is also assumed that $25 \%$ of this energy (or $22 \mathrm{MJ}$ ) goes jnto the production of steam even though without any steam production there would be less than a $55 \mathrm{C}$ average temperature in liquid within the critical volume. A volume of $16.7 \mathrm{~m}^{3}$ of steam is produced raising the pressure in the headspace of a full DST by about $0.002 \mathrm{MPa}\left(6.5\right.$ inches cf $\mathrm{H}_{2} 0$ ).

Number of fissions $\quad$ Burst $:=8) \cdot \mathrm{MJ}$ $\frac{\text { Burst }}{212 \cdot \frac{\mathrm{mev}}{\text { fission }}}=2.62 \cdot 10^{18}$-fission

Liquid Waste Values

Density of transfer liquid $\quad \rho_{\mathrm{w}: \mathrm{ste}}:=1.03 \cdot 10^{3} \cdot \frac{\mathrm{kg}}{\mathrm{m}^{3}} \quad$ heat capacity $\quad \mathrm{h}_{\mathrm{c}}:=4.2 \cdot \frac{\mathrm{joule}}{\mathrm{gm} \cdot \mathrm{K}}$ DST temperature heat of vaporization $h_{\text {vap }}:=2256 \cdot \frac{\text { joule }}{\mathrm{gm}}$

$$
\mathrm{T}_{\text {waste }}:=48 \cdot \mathrm{C}
$$$$
\text { density of steam } \quad v_{\text {steam }}:=1.6940 \cdot \frac{\mathrm{m}^{3}}{\mathrm{~kg}}
$$

It takes $66 \mathrm{MJ}$ to heat 300 liters of water from $48 \mathrm{C}(115 \mathrm{~F})$ to boiling

$$
\begin{gathered}
\left.{ }_{\text {heat }}^{\text {sensible }}=\left(100 \cdot \mathrm{C}-\mathrm{T}_{\text {waste }}\right) \cdot \mathrm{f}_{\text {waste }} \cdot \mathrm{h} \cdot \mathrm{c} / \mathrm{r} \text { crit }\right) \quad \frac{\text { Burst }- \text { heat }{ }_{\text {sensible }}}{\text { Burst }}=24.17 . \% \\
\text { Burst }- \text { heat }{ }_{\text {sensible }}=21.514 \cdot \mathrm{MJ}
\end{gathered}
$$

Starting from a liquid waste temperat ure of $48 \mathrm{C}$, a little less than $25 \%$ of the energy in the critical volume is available to create steam. This percentage is only an approximation since the temperatue distribution within the criti:al volume is not uniform. Recognizing this, the fraction of heat available to create steam is rcunded up to $25 \%$ to demonstrate the approximate nature of this value.

$$
\gamma:=25 \%
$$

$\gamma \cdot$ Burst $=22.25 \cdot \mathrm{MJ}$

Volume of steam
produced
Average temperature of liqt id when steam is pro luced

$$
\frac{(1-\gamma) \cdot \text { Burst }}{V\left(r_{\text {crit }}\right) \cdot \rho_{\text {waste }} \text { h }_{c}}+T_{\text {waste }}=99.433 \cdot \mathrm{C}
$$

$$
\begin{aligned}
& \text { steam }:=\frac{{ }^{\prime} \text { Burst }}{h_{\text {vap }}} \cdot v_{\text {steam }} \\
& \text { steam }=16.707 \cdot \mathrm{m}^{3}
\end{aligned}
$$




$\begin{array}{lll}\text { Headspace volume } & \text { headspac }:=1050 \cdot \mathrm{m}^{3} & \frac{\text { steam }}{1050 \cdot \mathrm{m}^{3}} \cdot \mathrm{atm}=1.612 \cdot 10^{-3} \cdot \mathrm{MPa} \\ \text { Pressure in headspace } & \frac{\text { steam }}{\text { headspa }: e}=1.6 \cdot 10^{-2} & \frac{\text { steam }}{1050 \cdot \mathrm{m}^{3}} \cdot \mathrm{atm}=6.473 \cdot \text { in_H2O }\end{array}$

\section{Release Amounts}

Source Term Analysis

The dose consequences include contributions from radioactive noble gases, iodine, and aerosolized plutcnium and tank waste. The source term for the tank waste and plutonium idertifies the amount of material released to the environment. The methodology and atmospheric constants used with the source term to calculate dose consequences are described in WHC-SD-WM-SAR-067, section 3.4.1 Methodology.

Constants from WHC-SD-SAR-0057, 3.4.1, Methodology Section

$$
\begin{gathered}
\mathrm{Br}:=3.3 \cdot 10^{-4} \cdot \frac{\mathrm{m}^{3}}{\mathrm{sec}} \quad \chi_{Q_{\text {onsite }}}:=3.41 \cdot 10^{-2} \cdot \frac{\mathrm{sec}}{\mathrm{m}^{3}} \quad \chi_{Q_{\text {offsite }}}=2.83 \cdot 10^{-5} \cdot \frac{\mathrm{sec}}{\mathrm{m}^{3}} \\
\text { ULD }:=6.0 \cdot 10^{3} \cdot \frac{\mathrm{Sv}}{\mathrm{liter}} \quad \mathrm{DCF}_{\mathrm{Pu} 239}=1.16 \cdot 10^{-4} \cdot \frac{\mathrm{Sv}}{\mathrm{Bq}}
\end{gathered}
$$

To find the quantity of material released into the headspace by the venting steam, the aerosol is assumed to comprise $0.05 \%$ of the salt content of the solution that is evaporated (NuReg 3.35). The 22 MJ is enough energy to evaporate 9.8 liters of liquid. The salt content of the waste is assumed to be equivalent to $10 \mathrm{~g} \mathrm{Pu}$ added to each liter of DST liquid. Applying the release fraction to the critical volume (300 liters) gives 0.0048 liters of DST waste and $48 \mathrm{mg}$ of pu released to the tank headspace. This gives concentrations of $4.56 \times 10^{-6}$ liter $\mathrm{DST} 1 \mathrm{iquid} / \mathrm{m}^{3}$ and $0.046 \mathrm{mg} \mathrm{Pu} / \mathrm{m}^{3}$ in the heidspace of a full DST.

"Aerosol should be assumed to compris? $0.05 \%$ of the salt content of the solution that is evaporated. The ventilation rate and retention time should be considered on an individual basis" NRC Regulatory Guide 3.35 page 5, Revision 1, July 1979.

Volume of headspace vented equals amount of steam produced

$$
\begin{array}{rrr}
\text { evap } & =\frac{\text { steam }}{v_{\text {steam }}} \cdot \frac{1}{\rho_{\text {waste }}} \quad \text { pf }:=0.05 \cdot \% \cdot \frac{\text { evap }}{V\left(r_{\text {crit }}\right)} \\
\text { evap } & =9.575 \cdot \text { liter } & \text { pf }=1.596 \cdot 10^{-5} \\
\text { vent volume } & \text {. steam } & \text { vent volume }=16.707 \cdot \mathrm{m}^{3}
\end{array}
$$


Waste Headspace loading based on a fraction of the $\mathrm{cr}$ tical volume

$$
\text { waste := } \frac{\mathrm{pf} \cdot \text { vo }}{\text { heads ume }}
$$

Plutonium pf volume $=4.788 \cdot 10^{-3} \cdot$ liter

$$
\text { waste }=4.56 \cdot 10^{-6} \cdot \frac{\text { liter }}{\mathrm{m}^{3}}
$$

$$
\text { pf } \cdot \text { volume } \cdot 10 \cdot \frac{\mathrm{gm}}{\text { liter }}=47.877 \cdot \mathrm{mg}
$$

$$
\mathrm{Pu}:=\frac{\text { pf volume } \cdot \mathrm{lC} \cdot \frac{\mathrm{gm}}{\text { liter }}}{\text { headspac } 2} \quad \mathrm{Pu}=0.046 \cdot \frac{\mathrm{mg}}{\mathrm{m}^{3}}
$$

To find the quantity of material released to the environment, the headspace concentrations are multiplied by the volume of steam $\left(16.7 \mathrm{~m}^{3}\right)$ vented from the headspace to the atmosphere. This gives $7.6 \times 10^{-5}$ liters of DST liquid and $0.76 \mathrm{mg}$ of $\mathrm{Pu}$ released to the environment.

$$
\begin{array}{cl}
\text { vent }_{\text {volume }}=16.707 \cdot \mathrm{m}^{3} & \frac{\text { pf } \cdot \text { vent } \text { volume }}{\text { headspace }}=2.539 \cdot 10^{-7} \\
\text { waste }_{\text {vent }}{ }_{\text {volume }}=7.618 \cdot 10^{-5} \cdot \text { liter } & \text { Pu-vent } \text { volume }=7.618 \cdot 10^{-4} \cdot \mathrm{gm}
\end{array}
$$

\section{Radiological Consequences}

\section{Consequences from DST liquid}

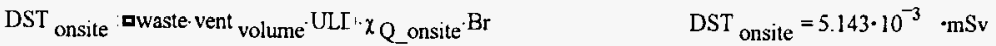

$$
\begin{aligned}
& \mathrm{DST}_{\text {offsite }}=\text { waste vent }_{\text {volume }} \cdot \mathrm{ULI}^{\cdot \chi_{Q_{2} \text { offsite }} \cdot \mathrm{Br}} \quad \mathrm{DST} \text { offsite }=4.269 \cdot 10^{-6} \cdot \mathrm{mSv}
\end{aligned}
$$

Consequences from PU release

$$
\begin{aligned}
& \mathrm{Pu}_{\text {onsite }}:=\mathrm{Pu} \cdot \text { vent }_{\text {volume }}^{-6.20 \cdot 10^{-2}} \cdot \frac{\mathrm{C}}{\mathrm{g} \text { l }} \cdot \mathrm{DCF}_{\mathrm{Pu} 239 \cdot \chi_{\mathrm{Q}} \text { onsite }} \cdot \mathrm{Br} \quad \mathrm{Pu} \text { onsite }=2.281 \cdot \mathrm{mSv}
\end{aligned}
$$

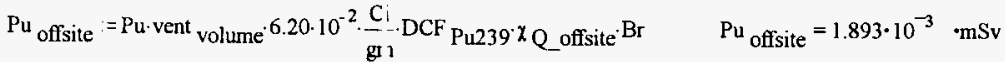


Hey's values can be used to calculate consequences for this accident by making corrections for the djfferent power levels and chi/Q values. Since the consequences are a lineal function of the number of fissions, Hey's consequences for the fission gases submersion and inhalation are ratioed by the respective number of total fissions (2.6 x 1018 and $\left.1 \times 10^{19}\right)$ to get consequences for the DST criticality. To first order, the Chi/Q correction is simply the ratjo of the respective chi/Qs.

\section{Consequence from Fission gas release (WHC-SD-WM-TI-52) based on NRC R.G. 3.35}

$$
\text { power ratio } \quad \eta:=\frac{89 \cdot \mathrm{MJ}}{350 \cdot \mathrm{MJ}}
$$

$$
r_{\text {onsi e }}:=\frac{0.034}{0.033} \quad r_{\text {offsite }}:=\frac{2.83 \cdot 10^{-5}}{2.21 \cdot 10^{-5}}
$$

inhalation

$$
\begin{aligned}
& \mathrm{FG}_{-}{ }_{\text {inh }} \text { onsite }=\eta \cdot \mathrm{r} \text { onsite }^{-8.5 \cdot \mathrm{rem}} \\
& \text { FG_inh }{ }_{\text {onsite }}=22 \cdot \mathrm{mSv} \\
& F G_{-} \text {inh offsite }=\eta \cdot r_{\text {offsite }} \cdot 3 \cdot 3 \cdot 10^{-3} \cdot \text { rem } \\
& \text { FG_inh } \text { offsite }=1.1 \cdot 10^{-2} \cdot \mathrm{mSv}
\end{aligned}
$$

submersion

$$
\begin{array}{ll}
F G_{-} \text {sub onsite }=\eta \cdot r_{\text {onsite }} \cdot 5.4 \cdot \mathrm{ren} & F G_{-} \text {sub onsite }=14 \cdot \mathrm{mSv} \\
F G_{-} \text {sub offsite }:=\eta \cdot \mathrm{r}_{\text {offsite }} \cdot 2.5 \cdot 10^{-3} \cdot \mathrm{rem} & F G_{-} \text {sub offsite }=8.1 \cdot 10^{-3} \cdot \mathrm{mSv}
\end{array}
$$

\section{Sum of the Radiological Cor sequences}

Onsite

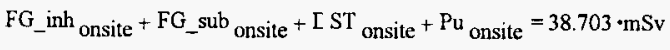

Offsite

$$
\mathrm{FG}_{-} \text {inh } \text { offsite }^{+} \mathrm{FG}_{-} \text {sub } \text { offsite }^{+I I S T} \text { offsite }+\mathrm{Pu}_{\text {offsite }}=0.021 \cdot \mathrm{mSv}
$$

Onsite guideline for "extremely unlikely" event

$100 \cdot \mathrm{mSv}$

Offsite guideline for "extremely unlikely" event

40. $\mathrm{mSv}$

\section{Toxicological Consequences}

The toxicological consequences sum-of-the-fractions methodology is described in reference wHC (1396a). Using the previously calculated value of $7.6 \times 10^{-5}$ liters of DST ljquid released to the environment in a puff release, the calculated onsit 3 and offsite toxicological consequences are:

Sum of the fraction numbers for an 'e stremely unlikely" event

$$
\begin{aligned}
& \text { SoF } \text { onsite }=6.0 \cdot 10^{1} \cdot \text { liter }^{-1} \\
& \text { SoF offsite }:=2.5 \cdot 10^{-3} \cdot \text { liter }^{-1} \\
& \text { waste vent } \text { volume } \text { SoF onsite }=4.571 \cdot 10^{-3} \quad \text { waste } \cdot \text { vent } \text { volume } \text { SoF offsite }=1.904 \cdot 10^{-7}
\end{aligned}
$$


The SoF are normalized such that if the product of the soF and the release amount is less than 1, the Rjsk Guidelines are met. Risk guidelines are therefore met for this event.

\section{Comparison to Risk Guidelines}

Although no credible scenaric has been identified for this accident implying a frequency beyond the "extremely unlikely" range (less than $\left.1^{-6}\right)$, both the onsite and of isite radiological doses are shown to be acceptable for an accident if the "unlikely" range (frequency of $10^{-2}$ to $10^{-4}$ per yearl. The toxicoloyical sum-of-fractions are below one for an anticipated event, and hence well below the risk evaluation guidelines, for both onsite and offsite receptors.

\section{Small tank Criticality Criticality in D-8}

For a criticality to occur ir a DST in the tank farm from a PEP transfer, there must be a failure to sample and record the transfer and the size of the transfer must also be linited to tens to hundreds of liters. A larger transfer has the potential for criticality occurring in the PFP receiver tank, D-8, or DCRT, 241-TX-244 before the waste reaches the DST.

For example, tank $\mathrm{D}-8$ has a $3 \mathrm{~m}$ diameter. Using an areal density of 240 $\mathrm{g} / \mathrm{ft}^{2}$, a transfer of more tha 1 1,800 liters of $10 \mathrm{~g} / \mathrm{L}$ Pu solution has the potential for a criticality in D-8. DCRT 241-TX-244 has larger dimensions and would require a larger transfer.

$$
\begin{array}{cc}
\text { minimum areal density } \left.\quad \rho_{\text {areal }}:=24\right) \cdot \frac{\mathrm{gm}}{\mathrm{f}^{2}} \quad \text { Receiver Tank D-8 diameter } \quad 10 \cdot \mathrm{ft}=3.048 \cdot \mathrm{m} \\
\pi \cdot\left(\frac{10 \cdot \mathrm{ft}}{2}\right)^{2} \cdot \rho_{\text {areal }}=18.85 \cdot \mathrm{kg} & \frac{\pi \cdot\left(\frac{10 \cdot \mathrm{ft}}{2}\right)^{2} \cdot \rho_{\text {areal }}}{10 \cdot \frac{\mathrm{gm}}{\text { liter }}}=1.885 \cdot 10^{3} \cdot \text { liter }
\end{array}
$$

\section{References}

Duderstadt J. J. and L. J. Hanilton, 1976, Nuclear Reactor Analysis, John wiley and Sons, New Yor 6 , New York.

Hetrick, D. L., 1993, Compute- Models for Predicting the Effects of Criticality Accidents i. Solutions, 1993 Topical Meeting on physics and Methods in Critical.ty Safety, Nashville, TN, september 19-23, 1993, pp. 80-86.

Hetrick, D.L., 1971, Dynamics of Nuclear Reactors, University of Chicago Press, Chicago, Illinoiis. 


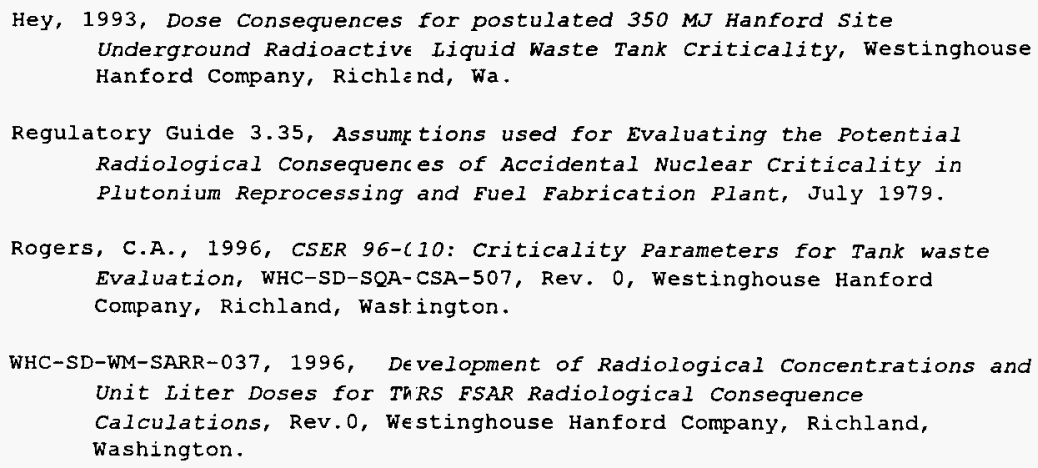

\section{Miscellaneous Constants and Conversions}

$\begin{array}{lllll}\mathrm{MPa} \equiv 10^{6} \cdot \mathrm{Pa} & \text { in_H2O } \equiv 1 \cdot \frac{\mathrm{gm}}{\mathrm{cm}^{3}} \cdot \mathrm{g} \cdot 1 \cdot \mathrm{in} & \mathrm{ev} \equiv 1.60219 \cdot 10^{-19} \cdot \text { joule } & \mathrm{MJ} \equiv 10^{6} \cdot \mathrm{joule} & \\ \text { dollar } \equiv 1 \quad \text { fission } \equiv 1 & \mathrm{~Sv} \equiv 1 \quad \mathrm{~Bq} \equiv 1 & \mathrm{rem} \equiv 10^{-2} \cdot \mathrm{Sv} & \\ \mathrm{Ci} \equiv 3.7 \cdot 10^{10} \cdot \mathrm{Bq} & \mathrm{F} \equiv \mathrm{R} & \mathrm{C} \equiv \mathrm{K} & \mathrm{mSv} \equiv 10^{-3} \cdot \mathrm{Sv} & \mathrm{mev} \equiv 10^{6} \cdot \mathrm{ev}\end{array}$




\section{PEER REVIEW CHECKLIST}

Document Reviewed: Calculation Note: that Support Accident Scenario and Consequence for [letermination of a Waste Tank Critica]ity

Author: R. D. Crowe

Date: July 31, 1996

Scope of Review: Dose calculation portion

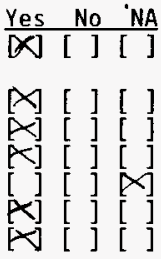

[ ] [ ] [י]

$\ll][$ ] [ ]

$\mathbb{P}[\mathrm{b}] \mathrm{i}$

$\left[\begin{array}{llll}] & {[} & {[} & {[} \\ {[} & {[} & {[}\end{array}\right]$

\&] [ ] [ ]

$\left[\begin{array}{lll}{[]} & {[} & \mathbb{2}\end{array}\right]$

$[\mathrm{C}][\mathrm{c}$

[ ] $[\mathrm{g}[\mathrm{C}]$

[ ] [ ] $[x]$

D] [ ] [ ] Document approved.

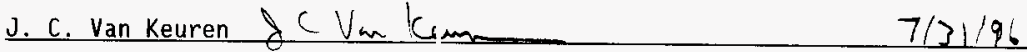

Reviewer (Printed Name and Signature)

Previous reviews conplete and cover analysis, up to scope of this review, with nc gaps.

Problem completely cefined.

Accident scenarios ceveloped in a clear and logical manner. Necessary assumptiors explicitly stated and supported.

Computer codes and cata files documented.

Data used in calculations explicitly stated in document.

Data checked for cor sistency with original source information as applicable.

Mathematical derivations checked including dimensional consistency of results.

Models appropriate and used within range of validity or use outside range of established validity justified.

Hand calculations checked for errors. Spreadsheet results should be treated exactly the same as hand calculations. Software input correct and consistent with document reviewed. Software output consistent with input and with results reported in document reviewed.

Limits/criteria/guidelines applied to analysis results are appropriate and referenced. Limits/criteria/guidelines checked against references.

Safety margins consistent with good engineering practices. Conclusions consistent with analytical results and applicable limits.

Results and conclusions address all points required in the problem statement.

Format consistent with appropriate NRC Regulatory Guide or other standards

Review calculations, comments, and/or notes are attached.

Date

HEDOP REVIEW CHECKLIST 


\section{CHECKLIST FOR INDEPENDENT REVIEN}

\section{Document Reviewed: Calculation Notes That Support Accident Scenario and}

Author: Ralph crowe

Yes № N/A

[x] [ ] [ ] Problen completely defined.

[x] [ ] [ ] Necessary assumptions expl citly stated and supported.

[x] [ ] [ ] Computer codes and data files documented.

[x] [ ] [ ] Data checked for consistency with original source information os applicable.

[x] [ ] [ ] Mathematical derivations ct ecked including dimensional consistency of results.

[X] [ ] [ ] Models appropriate and usex within range of validity or use outside range of established validity justified.

[x] [ ] [ ] Hand calculations checked tor errors.

[ ] [ ] [x] Code run streams correct ard consistent with analysis documentation.

[ ] [ ] [X] code output consistent with input and with results reported in analysis documentation.

[x] [ ] [ ]

Acceptability limits on ant lytical results applicable and supported. Limits checked against sources.

[x] [ ] [ ] Safety margins consistent , ith good engineering practices.

[x] [ ] [ ] Conelusions consistent with analytical results and applicable limits.

[x] [ ] [ ] Results and conclusions adcress all points required in the problem stetement.

[x] [ ] [ ] Have all reasonable accider ts been considered?

[ ] [ ] $[\mathrm{X}]$ Has Low density water (stea $n$ ) been evaluated as a moderator?

[X] [ ] [ ] is the fuel and other hardhare composition correct?

[x] [ ] [ ] Are the cases considered co 1 servative? Too conservative?

[ ] [ ] [x] Do the computer models adeq Jately reflect the actual geometry? Have cross sectional cuts of the geometry been made and do they show the desired geometry?

[x] [ ] [ ] Has the analysis been revieked by Safety this may not be required in a preliminary design.

[x] [ ] [ ] Has the reviewer completed the Criticality Safety Course for Managers and Engineers? Date completed May, lias

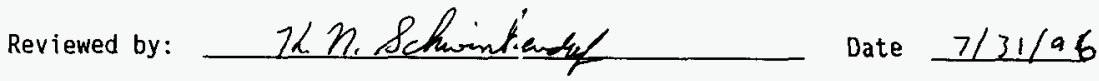

NOTE: Any hand calculations, notes, or summaries generated as part of this review should be signed, dated, and attached to this checklist. Materials should be labeled and recorded so that it is intelligible to a technically-qualified third party. 


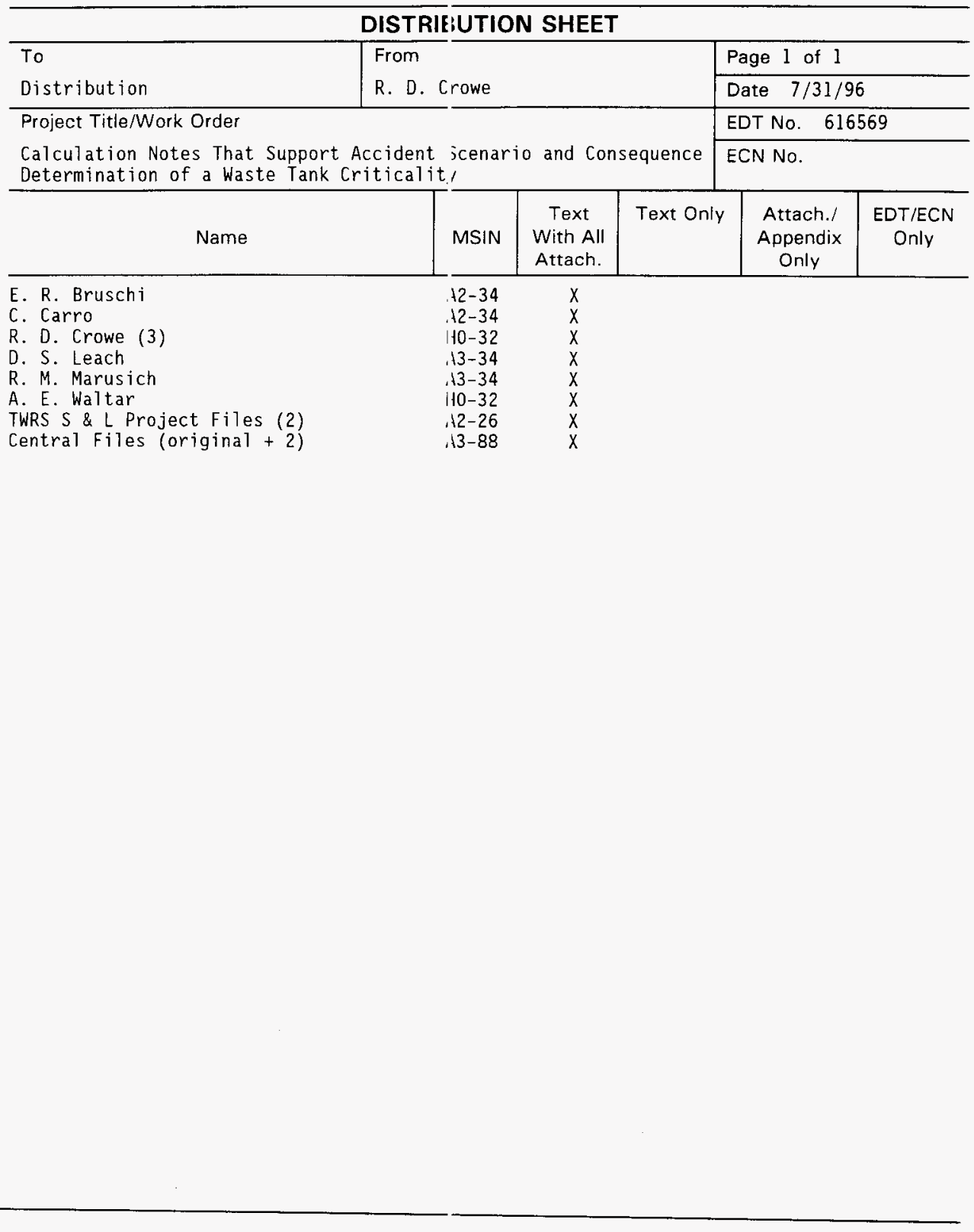

